\title{
Detection of Sugarcane yellow leaf virus in Quarantine and Production of Virus-free Sugarcane by Apical Meristem Culture
}

\author{
M. Chatenet, C. Delage, and M. Ripolles, Centre de Coopération Internationale en Recherche Agronomique pour \\ le Développement (CIRAD), TA 71/09, 34398 Montpellier Cedex 5, France; M. Irey, U.S. Sugar Corporation, P.O. \\ Drawer 1207, Clewiston, FL 3340; B. E. L. Lockhart, Department of Plant Pathology, University of Minnesota, St. \\ Paul 55108; and P. Rott, Centre de Coopération Internationale en Recherche Agronomique pour le Développement \\ (CIRAD), TA 71/09, 34398 Montpellier Cedex 5, France
}

\begin{abstract}
Chatenet, M., Delage, C., Ripolles, M., Irey, M., Lockhart, B. E. L., and Rott, P. 2001. Detection of Sugarcane yellow leaf virus in quarantine and production of virus-free sugarcane by apical meristem culture. Plant Dis. 85:1177-1180.

Sugarcane yellow leaf virus (SCYLV) was detected for the first time in 1996 in the Centre de Coopération Internationale en Recherche Agronomique pour le Développement (CIRAD) sugarcane quarantine at Montpellier by reverse transcription-polymerase chain reaction (RT-PCR) in varieties from Brazil, Florida, Mauritius, and Réunion. Between 1997 and 2000, the virus was found by RT-PCR and/or tissue-blot immunoassay (TBIA) in additional varieties from Barbados, Cuba, Guadeloupe, Indonesia, Malaysia, Philippines, Puerto Rico, and Taiwan, suggesting a worldwide distribution of the pathogen. An excellent correlation was observed between results obtained for the two diagnostic techniques. However, even though only a few false negative results were obtained by either technique, both are now used to detect SCYLV in CIRAD's sugarcane quarantine in Montpellier. The pathogen was detected by TBIA or RT-PCR in all leaves of sugarcane foliage, but the highest percentage of infected vascular bundles was found in the top leaves. The long hot water treatment (soaking of cuttings in water at $25^{\circ} \mathrm{C}$ for 2 days and then at $50^{\circ} \mathrm{C}$ for $3 \mathrm{~h}$ ) was ineffective in eliminating SCYLV from infected plants. Sugarcane varieties from various origins were grown in vitro by apical bud culture and apical meristem culture, and the latter proved to be the most effective method for producing SCYLV-free plants.
\end{abstract}

Sugarcane (Saccharum spp.) productivity can be maintained through steady efforts to enhance the varietal status (i.e., all varieties grown in an area at a given time) by introducing new varieties. However, sugarcane crops are especially vulnerable to diseases because of various factors: propagation from cuttings facilitates the spread of pathogens; monocropping over large areas is favorable to the development of epidemics; and the pluriannual aspect of this crop (4 to 10 years on average) lengthens and complicates breeding. Sugarcane stalks can be infected by various pathogens without exhibiting any symptoms, and therefore there is a high risk of disease transmission during exchange and transport of sugarcane cuttings. In order to control these diseases, the Centre de Coopération Internationale en Recherche Agronomique pour le Développement (CIRAD) set up in 1971 a sugarcane quarantine unit in Nogent-sur-Marne near Paris, France, which was transferred to Montpellier in 1978.

Corresponding author: P. Rott

E-mail: philippe.rott@cirad.fr

Accepted for publication 12 July 2001.

Publication no. D-2001-0830-01R

(C) 2001 The American Phytopathological Society
The objective of this unit is to supply disease-free cuttings, mainly to sugarproducing areas of western and central Africa, and to sugarcane breeding stations in the West Indies (Guadeloupe and Barbados), the Mascareignes (Réunion Island), and others.

Yellow leaf syndrome (YLS) of sugarcane is a disease that has recently been associated with Sugarcane yellow leaf virus (SCYLV), an unclassified member of the Luteoviridae $(10,12,17,19,20)$. In some cases, YLS has also been associated with one or several phytoplasmas $(4,5,10)$. A characteristic symptom of the disease is the yellowing of the leaf midrib, and this discoloration often occurs while the lamina is still green. Symptoms also include shortening of terminal internodes, yellowing and necrosis of leaves, and sucrose accumulation in midribs. Visual symptoms are generally not reliable for identifying the disease because leaf yellowing can also be caused by several other biotic and abiotic factors (10). Additionally, sugarcane can be infected by SCYLV without exhibiting any symptoms.

Three diagnostic tests have been developed for the detection of SCYLV. The first two tests are serological techniques called tissue-blot immunoassay (TBIA) and double-antibody sandwich enzyme-linked immunosorbent assay (DAS-ELISA), and the third test is based on reverse transcription-polymerase chain reaction (RT-PCR) $(3,18)$. Both TBIA and RT-PCR have been successfully used to detect the presence of the virus in various sugarcane growing locations such as Cuba (1), Florida (3), Guadeloupe (7), Hawaii (18), Martinique (7), Réunion Island (14), and South Africa (5). YLS has so far been found in more than 30 countries, and yield losses higher than $20 \%$ due to SCYLV have been reported in susceptible cultivar SP71-6163 in Brazil (10). Therefore, careful attention must be paid to this virus when sugarcane germ plasm is exchanged between countries.

Approximately 100 sugarcane clones are imported and an equal number are released every year by the quarantine unit of CIRAD in Montpellier $(15,16)$. Since 1996, more than 300 clones from 13 locations were tested for the presence of SCYLV by RT-PCR and/or TBIA. The objectives of our study were: first, to compare TBIA and RT-PCR in the detection of SCYLV; second, to examine the distribution of SCYLV in sugarcane plants; and third, to compare techniques (hot water treatment and tissue culture) for the elimination of SCYLV from sugarcane.

\section{MATERIALS AND METHODS}

Growth of sugarcane in quarantine. Sugarcane plants were grown in pots in greenhouses as described by Rott et al. $(15,16)$. Briefly, varieties to be quarantined were sent directly by the source country to Montpellier. After cuttings were germinated in a climate-controlled room at 28 to $30^{\circ} \mathrm{C}$, the young shoots were planted in 7.5-liter pots containing a mixture of peat moss, compost, and volcanic rock (2/5:2/5:1/5, vol/vol/vol), drip watered, and placed in quarantine greenhouse $n^{\circ} 1$ (first growth cycle). Only primary stalks were grown, and secondary tillers were regularly removed from the pot. The canes were treated with fungicides (benomyl at 0.5 $\mathrm{g} /$ liter, fosetyl-al at $0.8 \mathrm{~g} /$ liter) and insecticides (deltamethrin at $25 \mathrm{mg} /$ liter, aldicarb at $0.1 \mathrm{~g}$ per pot) at planting and several times during their growth cycle. They were visually inspected regularly, and various methods such as isolation on selective media, serological techniques, and molecular techniques were applied to detect sug- 
arcane pathogens. RT-PCR and TBIA were used to specifically detect SCYLV. The sugarcane stalks were cut and heat treated (cuttings soaked in water at $25^{\circ} \mathrm{C}$ for 2 days, and then at $50^{\circ} \mathrm{C}$ for $3 \mathrm{~h}$ ) at the end of the 9- to 12-month growth cycle. Thereafter, the hot water-treated cuttings were planted in 10-liter pots in quarantine greenhouse $n^{\circ} 2$ (second growth cycle). The plants were once more inspected and treated with insecticides (deltamethrin at $25 \mathrm{mg} /$ liter, aldicarb at $0.1 \mathrm{~g}$ per pot). After 9 to 12 months of growth, stalks were harvested and cuttings were subject to a short heat treatment (soaking in hot water for $1 \mathrm{~h}$ at $50^{\circ} \mathrm{C}$ ) and dipped into a fungicide (benomyl at $0.5 \mathrm{~g} / \mathrm{liter}$ ). These cuttings were then dispatched from the quarantine unit.

Meristem and bud cultures. Ca. $5 \times 2$ $\mathrm{cm}$ fragments containing the apical meristem and buds were sampled from the tops of 3- to 14-month-old sugarcane stalks. The fragments were then dipped for $10 \mathrm{~min}$ in a bleach solution $\left(24^{\circ}\right)$ and rinsed twice for $10 \mathrm{~min}$ in sterile distilled water. Outer leaves were removed, and the true meristem $(300$ to $500 \mu \mathrm{m})$ and buds (stalk disks with individual buds) were excised and placed on growth medium. Meristem and bud growth was initiated in petri dishes containing Murashige and Skoog medium (MS) (13) complemented with sucrose at 60 g/liter, Fujii vitamins (9), activated charcoal at $3.5 \mathrm{~g} / \mathrm{liter}$, and Phytagel at 3 $\mathrm{g} /$ liter. Meristems and buds were cultured at $28^{\circ} \mathrm{C}$ with a light photoperiod of $12 \mathrm{~h}$, but the meristems were kept in the dark for 1 week before being transferred to light on fresh medium. Plantlets issued from meristems or buds were transferred to $200 \times 24$ $\mathrm{mm}$ glass tubes on fresh medium without activated charcoal. After 6 to 8 months of growth, well-rooted plantlets were transplanted to the quarantine greenhouses.

SCYLV detection. Except when otherwise stated, the top visible dewlap leaf was used for pathogen detection in plants grown in the greenhouse. All leaves were sampled for pathogen detection in tissue cultured sugarcane plantlets. RT-PCR was performed as described by Comstock et al. (3), except that total RNA was extracted from leaf midribs with the RNeasy Plant extraction kit (QIAGEN, Courtaboeuf, France). TBIA was performed as described by Schenck et al. (18), except nitrocellulose membranes and Fast Blue BB salt (Sigma, St. Quentin Fallavier, France) were used. TBIA membranes were observed with a stereomicroscope $(\times 100)$ to determine positive reactions, which appeared as dark blue spots coincident with the vascular bundles.

Distribution of SCYLV in the foliage of sugarcane plants. Three different sets of stalks were used: 24 stalks representing 24 varieties in a first set, 25 stalks from 16 varieties in a second set, and 12 stalks from

Table 1. Detection of Sugarcane yellow leaf virus in quarantine during the first growth cycle

\begin{tabular}{|c|c|c|c|c|}
\hline \multirow[b]{2}{*}{ Quarantine season } & \multirow{2}{*}{$\begin{array}{c}\text { Commercial } \\
\text { varieties }\end{array}$} & \multicolumn{2}{|c|}{ Varieties in final stage of selection } & \multirow{2}{*}{$\begin{array}{c}\text { Detection } \\
\text { method }^{z}\end{array}$} \\
\hline & & Guadeloupe & Barbados & \\
\hline July 1996-June 1997 & $17+/ 26(65 \%)$ & - & - & RT-PCR \\
\hline July 1997-June 1998 & $14+/ 29(48 \%)$ & $12+/ 50(24 \%)$ & $0 / 51$ & RT-PCR \\
\hline July 1998-June 1999 & $4+/ 12(33 \%)$ & $23+/ 54(43 \%)$ & $4+/ 29(14 \%)$ & RT-PCR \\
\hline July 1999-June 2000 & $13+/ 23(56 \%)$ & $2+/ 52(4 \%)$ & $0 / 56$ & RT-PCR + TBIA \\
\hline
\end{tabular}

${ }^{\mathrm{z}}$ TBIA $=$ tissue-blot immunoassay, and RT-PCR $=$ reverse transcription-polymerase chain reaction.

Table 2. Detection of Sugarcane yellow leaf virus in quarantine during the second growth cycle

\begin{tabular}{lcccc}
\hline Quarantine season & $\begin{array}{c}\text { Commercial } \\
\text { varieties }\end{array}$ & \multicolumn{2}{c}{ Varieties in final stage of selection } & \multirow{2}{*}{$\begin{array}{c}\text { Detection } \\
\text { [nethod }\end{array}$} \\
\hline July 1996-June 1997 & $12+/ 18(66 \%)$ & $8+/ 40(20 \%)$ & $0 / 42$ & RT-PCR \\
July 1997-June 1998 & $0 / 10$ & $6+/ 49(12 \%)$ & $0 / 38$ & RT-PCR \\
July 1998-June 1999 & $0 / 10$ & $6+/ 38(15 \%)$ & $0 / 57$ & TBIA \\
July 1999-June 2000 & $2+/ 24(8 \%)$ & $7+/ 33(21 \%)$ & $0 / 35$ & TBIA \\
\hline
\end{tabular}

${ }_{\mathrm{z}}^{\mathrm{z}} \mathrm{TBIA}=$ tissue-blot immunoassay, and RT-PCR $=$ reverse transcription-polymerase chain reaction.

Table 3. Efficacy of hot water treatment of cuttings and tissue culture for the elimination of Sugarcane yellow leaf virus (SCYLV) in sugarcane

\begin{tabular}{lcccc}
\hline $\begin{array}{l}\text { Infection status } \\
\text { of stalks before } \\
\text { treatment }\end{array}$ & $\begin{array}{c}\text { Virus-free stalks/total } \\
\text { stalks from hot water } \\
\text { treated cuttings }\end{array}$ & $\begin{array}{c}\text { Virus-free plantlets/total } \\
\text { plantlets by apical } \\
\text { meristem culture }\end{array}$ & $\begin{array}{c}\text { Virus-free } \\
\text { plantlets/total plantlets } \\
\text { by apical bud culture }\end{array}$ \\
\hline Positive & $0 / 6$ & $136 / 147(92 \%)$ & $105 / 365(29 \%)$ \\
Negative & $273 / 288(95 \%)$ & & \\
Unknown & $80 / 100(80 \%)$ & & \\
\hline
\end{tabular}

$\bar{x}$ Positive $=$ SCYLV detected by tissue-blot immunoassay (TBIA) or reverse transcriptionpolymerase chain reaction (RT-PCR); negative $=$ SCYLV not detected by TBIA or RT-PCR.

y One stalk per cutting and variety; second growth cycle of plants in quarantine.

${ }^{\mathrm{z}}$ Issued from 60 varieties.

four varieties in a third set. All available leaves from the spindle leaves (LO) to the twelfth visible dewlap leaf $(\mathrm{L}+12)$ were sampled from each stalk and assayed with tissue blots of cross-sectioned leaf blade midribs. TBIA membranes were observed with a stereomicroscope $(\times 100)$ to count the number of infected vascular bundles and the total number of vascular bundles in each leaf midrib imprint. A leaf was considered infected by SCYLV when at least one vascular bundle showed a positive reaction.

Statistical analysis. Data on the incidence of vascular bundle colonization were analyzed for significance using chi-square test by the SAS software (SAS Institute, Cary, NC) with FREQ procedure. Only leaf ranks for which more than 10 leaves were sampled per set of stalks were taken into consideration for statistical analysis (rank L0 to $\mathrm{L}+8$ in set 1 , rank $\mathrm{L} 0$ to $\mathrm{L}+7$ in set 2, rank L0 to L+3 in set 3 ). When chisquare results were significant, the ratios "number of infected vascular bundles/number of observed vascular bundles" were compared using Goodman's multiple comparison test (11).

\section{RESULTS AND DISCUSSION}

SCYLV was detected by RT-PCR for the first time in CIRAD's sugarcane quarantine during the 1996-97 season and both growth cycles: 29 out of $44(66 \%)$ of the international sugarcane varieties were infected by the pathogen (Tables 1 and 2). These varieties were from Florida, Brazil, Mauritius, and Réunion Island. The presence of the pathogen in canes of the second growth cycle was a first proof that the long hot water treatment applied between the two quarantine cycles was not effective in eliminating the pathogen in infected cuttings. Between 1997 and 2000, during the first growth cycle, the virus was found by RT-PCR and/or TBIA in 31 out of 64 $(48 \%)$ other varieties that had come from Puerto Rico, Taiwan, Cuba, the Philippines, Indonesia, and Malaysia (Table 1). SCYLV was not found in canes from Sudan. Thirty-seven (24\%) out of 156 varieties in the final stage of selection from Guadeloupe and 4 (3\%) out of 136 from Barbados were also infected by SCYLV, suggesting a worldwide distribution of this pathogen.

Table 4. Comparison of reverse transcriptionpolymerase chain reaction (RT-PCR) and tissue-blot immunoassay (TBIA) detection of Sugarcane yellow leaf virus

\begin{tabular}{ccc}
\hline \multicolumn{2}{c}{$\begin{array}{c}\text { Observed combination } \\
\text { of results }\end{array}$} & \\
\cline { 1 - 2 } TBIA & RT-PCR & Stalks \\
\cline { 1 - 2 }$++^{\mathrm{y}}$ & + & 64 \\
- & - & 0 \\
+ & - & $2^{\mathrm{z}}$ \\
- & + & 1 \\
\hline $\mathrm{y}$ & & \multicolumn{2}{c}{ negative result; + = positive result. } \\
$\mathrm{z}$
\end{tabular}

${ }^{\mathrm{z}}$ RT-PCR+ after dilution of the RNA sample. 
The virus was detected in many fewer varieties during the second quarantine growth cycle between 1997 and 2000, because most varieties were removed from quarantine after being found infected during the first growth cycle (Table 2). Six varieties known to be infected in the first growth cycle were still infected during the second quarantine cycle after application of the long hot water treatment (Table 3). The pathogen was, however, also detected in $15(5 \%)$ out of 288 varieties that tested negative during the first growth cycle. These unexpected results could be due to false negative reactions because, until 1999, only one diagnostic test (RT-PCR or TBIA) was carried out during the first quarantine cycle. Variations in diagnostic results between RT-PCR, DAS-ELISA, and TBIA were recently reported by Comstock et al. in their study of the incidence of yellow leaf syndrome in Florida, Louisiana, and Texas (3). Another possibility could be the uneven distribution of the virus in the plant. Recent observations in Guadeloupe indicated that, in some varieties, the pathogen can be detected by TBIA in the leaves but not in the stalks and vice versa (6).

Sixty-seven stalks were tested by RTPCR and TBIA, and an excellent correlation between the two techniques was observed in all but three samples (Table 4). One sample was negative by TBIA and positive by RT-PCR; it was assumed that in this case the amount of virus particles in the leaf was below the detection threshold of TBIA. Two samples were positive by TBIA and negative by RT-PCR. After diluting the RNA extract, the RT-PCR was positive, suggesting that, in the first attempt, the reaction was inhibited by either too much viral RNA or PCR inhibitors. Because of all the results mentioned above, RT-PCR and TBIA are now simultaneously used to detect SCYLV in the leaves of sugarcane varieties in quarantine during the first growth cycle. TBIA is also used to detect the pathogen in stalks at the end of the first growth cycle and in leaves during the second growth cycle.
The pathogen was distributed in almost all the foliage of sugarcane plants, from the spindle leaves to the twelfth visible dewlap leaf. SCYLV was detected in $216(96 \%)$ out of 225 leaves, 175 (92\%) out of 190 leaves, and 75 (99\%) out of 76 leaves in the first, second, and third set of stalks, respectively. Negative results were more frequently observed for spindle and older leaves but were also obtained for other leaf ranks. The 15-leaf samples that were negative by TBIA for the second set of stalks were found positive by RT-PCR. These results indicated that all leaves of a stalk are generally infected but that virus titer may vary among leaves and may be below the detection threshold of the serological technique. Incidence of vascular bundle colonization was determined for the series of leaves from the oldest spindle leaf (L0) to the eighth visible dewlap leaf $(\mathrm{L}+8)$ of the same three sets of stalks, when more than 10 leaves were available per leaf rank. The mean percentage of infected vascular bundles in leaf midribs varied between 44 and $88 \%$ (Table 5). Furthermore, the incidence of vascular bundle colonization differed between the upper and the lower foliar ranks in the first two sets of stalks (Tables 5 and 6). Highest values were observed for the top leaves ( $\mathrm{L} 0$ to $\mathrm{L}+4$ in set 1, L0 to L+2 in set 2), which showed that these leaves are the most appropriate for detection of the pathogen. Indeed, the top visible dewlap leaf $(\mathrm{L}+1)$ is mostly used for SCYLV diagnosis, whatever the laboratory and the technique $(3,7,14,18)$.

The presence of SCYLV in numerous varieties was a major concern because pathogen-infected material was expected to be eliminated in quarantine. If SCYLV was not controlled, only a few varieties would be able to be released to the users of the quarantine. Additionally, the long hot water treatment, which is recommended for the safe movement of sugarcane germ plasm (2), was not effective in eliminating the virus from infected cuttings: from 1997 to 2000,41 out of 394 stalks were found infected by the pathogen during the second growth cycle after application of the hot water treatment (Table 3). Because of the high percentage of infected valuable material, a tissue culture program was started to produce healthy plants (8). Two techniques, apical meristem culture and apical bud culture, were compared. Sixty SCYLV-infected varieties from eight countries were grown in vitro by apical meristem culture. A total of 147 tissue cultured plantlets were produced, which were tested for SCYLV by RT-PCR. Of the 147 plantlets, $136(92 \%)$ tested negative for the virus (Table 3 ). The rest were still infected. Forty varieties (one plantlet per variety from the set of 136 virus-free plantlets) were transferred to the greenhouse, and SCYLV was not detected by RT-PCR in any of the 6-month-old plants. Sixty varieties were also grown in vitro by apical bud culture, and 365 tissue cultured plantlets were produced. Among those, only 105 $(29 \%)$ were found to be free of the virus. Apical meristem culture therefore proved to be the most efficient in producing virusfree plantlets and a method of choice to eliminate viral pathogens from infected plants. Thanks to this research, it will be possible to continue the distribution and exchange of sugarcane germ plasm with very low risk of introducing SCYLV in other countries. Moreover, tissue culture techniques can be efficiently used to obtain virus-free sugarcane for epidemiological studies and to evaluate yield losses due to this virus.

Table 6. Probability values from chi-square $\left(\chi^{2}\right)$ analysis of the ratio number of infected vascular bundles/number of observed vascular bundles

\begin{tabular}{lccc}
\hline Foliar rank effect & df & $\chi^{\mathbf{2}}$ & Probability \\
\hline Set 1 & 8 & 131.276 & 0.0001 \\
Set 2 & 7 & 71.806 & 0.0001 \\
Set 3 & 3 & 7.355 & 0.0614 \\
\hline
\end{tabular}

Table 5. Incidence of vascular bundle colonization in leaf midribs of three sets of sugarcane stalks infected by Sugarcane yellow leaf virus

\begin{tabular}{|c|c|c|c|c|c|c|c|}
\hline \multirow[b]{2}{*}{ Foliar rank } & \multicolumn{2}{|c|}{ Set $1^{w}$} & \multicolumn{2}{|c|}{ Set $2^{w}$} & \multicolumn{2}{|c|}{ Set $3^{x}$} & \multirow[b]{2}{*}{$\begin{array}{l}\text { Mean \% infected } \\
\text { vascular bundles }\end{array}$} \\
\hline & $\begin{array}{l}\text { Leaves from } \\
24 \text { stalks }^{y}\end{array}$ & $\begin{array}{c}\text { Infected/observed } \\
\text { vascular bundles }\end{array}$ & $\begin{array}{l}\text { Leaves from } \\
25 \text { stalks }^{\mathrm{y}}\end{array}$ & $\begin{array}{l}\text { Infected/observed } \\
\text { vascular bundles }\end{array}$ & $\begin{array}{l}\text { Leaves from } \\
12 \text { stalks }^{y}\end{array}$ & $\begin{array}{l}\text { Infected/observed } \\
\text { vascular bundles }\end{array}$ & \\
\hline L0 & 16 & $171 / 240(71 \%) \mathrm{ab}^{\mathrm{z}}$ & 17 & $174 / 227(77 \%) a b^{\mathrm{z}}$ & 10 & $137 / 170(81 \%)$ & 76 \\
\hline $\mathrm{L}+1$ & 24 & $265 / 338(78 \%) a$ & 23 & $288 / 357(81 \%) \mathrm{a}$ & 10 & $145 / 164(88 \%)$ & 82 \\
\hline $\mathrm{L}+2$ & 22 & $243 / 310(78 \%) \mathrm{a}$ & 24 & $257 / 330(78 \%)$ a & 10 & $130 / 161(81 \%)$ & 79 \\
\hline $\mathrm{L}+3$ & 22 & $235 / 310(76 \%) \mathrm{a}$ & 22 & $175 / 282(62 \%) b c$ & 11 & $141 / 182(77 \%)$ & 72 \\
\hline $\mathrm{L}+4$ & 22 & $211 / 296(71 \%) a b$ & 16 & $147 / 209(70 \%) \mathrm{abc}$ & - & - & 70 \\
\hline $\mathrm{L}+5$ & 22 & $172 / 291(59 \%) b c$ & 13 & $87 / 153(57 \%) \mathrm{c}$ & - & - & 58 \\
\hline $\mathrm{L}+6$ & 21 & $223 / 319(70 \%) a b$ & 12 & $79 / 130(61 \%) b c$ & - & - & 65 \\
\hline $\mathrm{L}+7$ & 15 & $103 / 219(47 \%) \mathrm{c}$ & 10 & $61 / 110(55 \%) \mathrm{c}$ & - & - & 51 \\
\hline $\mathrm{L}+8$ & 11 & $64 / 144(44 \%) \mathrm{c}$ & - & - & - & - & - \\
\hline
\end{tabular}

w 11 -month-old stalks (20 to 25 internodes).

x 5- to 12-month-old stalks.

y Dead leaves or leaves that did not yield good quality imprints were not assayed.

${ }^{\mathrm{z}}$ Ratios followed by the same letter are not significantly different $(P=0.05)$ according to Goodman's multiple comparison test. 


\section{ACKNOWLEDGMENTS}

We thank F. Paulet, M. J. Darroussat, M. Muller, and J. F. Bousquet for excellent technical assistance and P. Feldmann for fruitful discussions. We thank P. Letourmy and J. Chaume for statistical analysis of data.

\section{LITERATURE CITED}

1. Arocha, Y., Gonzalez, L., Peralta, E. L., and Jones, P. 1999. First report of virus and phytoplasma pathogens associated with yellow leaf syndrome of sugarcane in Cuba. Plant Dis. 83:1177.

2. Bailey, R. A., Comstock, J. C., Croft, B. J., Saumtally, A. S., and Rott, P. 2000. Procedures for the safe movement of sugarcane germplasm. Pages 311-315 in: A Guide to Sugarcane Diseases. P. Rott, R. A. Bailey, J. C. Comstock, B. J. Croft, and A. S. Saumtally, eds. La Librairie du Cirad, Montpellier.

3. Comstock, J. C., Irey, M. S., Lockhart, B. E. L., and Wang, Z. K. 1998. Incidence of yellow leaf syndrome in $\mathrm{CP}$ cultivars based on polymerase chain reaction and serological techniques. Sugar Cane 4:21-24.

4. Cronjé, C. P. R., Bailey, R. A., and McFarlane, K. 1998. Update on the occurrence of yellow leaf syndrome in the South African sugar industry and evidence for the causal organism. Proc. Annu. Congr. S. Afr. Sugar Tech. Assoc. 72:81-84.

5. Cronjé, C. P. R., Tymon, A. M., Jones, P., and Bailey, R. 1998. Association of a phytoplasma with a yellow leaf syndrome of sugarcane in
Africa. Ann. Appl. Biol. 133:177-186.

6. Daugrois, J. H., Boisne-Noc, R., and Rott, P. 2000. Testing sugarcane for resistance to Sugarcane yellow leaf virus. Page Ph-8 in: Abstr. Int. Soc. Sugar Cane Technol. Pathol. Workshop, 6th.

7. Daugrois, J. H., Jean-Baptiste, I., Lockhart, B. E. L., Irey, M. S., Chatenet, M., and Rott, P. 1999. First report of sugarcane yellow leaf virus in the French West Indies. Plant Dis. 83:588.

8. Faccioli, G., and Marani, F. 1998. Virus elimination by meristem tip culture and tip micrografting. Pages 346-380 in: Plant Virus Disease Control. A. Hadidi, R. K. Khetarpal, H. Koganezawa, eds. American Phytopathological Society, St. Paul, MN.

9. Fujii, T. 1970. Callus formation in wheat anthers. Inform. Serv. 31:1-2.

10. Lockhart, B. E., and Cronjé, C. P. R. 2000. Yellow leaf syndrome. Pages 291-295 in: A Guide to Sugarcane Diseases. P. Rott, R. A. Bailey, J. C. Comstock, B. J. Croft, and A. S. Saumtally, eds. La Librairie du Cirad, Montpellier.

11. Miller, R. G., Jr. 1981. Simultaneous Statistical Inference. 2nd ed. Springer-Verlag, New York.

12. Moonan, F., Molina, J., and Mirkov, T. E. 2000. Sugarcane yellow leaf virus: An emerging virus that has evolved by recombination between luteoviral and poleroviral ancestors. Virology 169:156-171.

13. Murashige, T., and Skoog, F. 1962. A revised medium for rapid growth and bioassays with tobacco tissue cultures. Physiol. Plant. 15:473-497.

14. Rassaby, L., Girard, J. C., Irey, M. S., Lockhart, B. E. L., and Rott, P. 1999. Survey of sugarcane yellow leaf syndrome in Réunion Island. Sugar Cane October:16-18.

15. Rott, P., Bousquet, J. F., Chatenet, M., Darroussat, M. J., Muller, M., and Ripolles, M 1998. A quarantine unit in Montpellier (France) for safe movement of sugarcane germplasm. Abstr. 4.6.1 In: Abstr. Int. Congr. Plant Pathol., 7th.

16. Rott, P., Bousquet, J. F., Muller, M., and Chatenet, M. 1997. La quarantaine de canne à sucre du CIRAD à Montpellier. Agric. Dével. 13:22-28.

17. Scagliusi, S. M., and Lockhart, B. E. L. 2000. Transmission, characterization, and serology of a luteovirus associated with yellow leaf syndrome of sugarcane. Phytopathology 90:120-124.

18. Schenck, S., Hu, J. S., and Lockhart, B. E. 1997. Use of a tissue blot immunoassay to determine the distribution of sugarcane yellowleaf virus in Hawaii. Sugar Cane 4:5-8.

19. Smith, G. R., Borg, Z., Lockhart, B. E. L., Braithwaite, K. S., and Gibbs, M. 2000. Sugarcane yellow leaf virus: A novel member of the Luteoviridae that probably arose by interspecies recombination. J. Gen. Virol 81:1865-1869.

20. Vega, J., Scagliusi, S. M. M., and Ulian, E. C. 1977. Sugarcane yellow leaf disease in Brazil: Evidence of association with a luteovirus. Plant Dis. 81:21-26. 